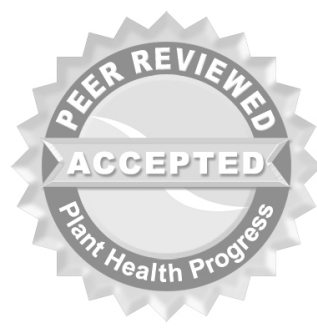

(c) 2006 Plant Management Network.

Accepted for publication 25 October 2006. Published 14 December 2006.

\title{
First Report of Powdery Mildew Caused by Golovinomyces cichoracearum on Coreopsis leavenworthii
}

Teresa E. Seijo, Senior Biological Scientist, David Czarnecki, Graduate Student, Environmental Horticulture Department, Zhanao Deng, Assistant Professor, Environmental Horticulture Department, and Natalia A. Peres, Assistant Professor, Gulf Coast Research and Education Center, Department of Plant Pathology, University of Florida-IFAS, Wimauma 33598

Corresponding author: Teresa E. Seijo. tseijo@ufl.edu

Seijo, T. E., Czarnecki, D., Deng, Z., and Peres, N. A. 2006. First report of powdery mildew caused by Golovinomyces cichoracearum on Coreopsis leavenworthii. Online. Plant Health Progress doi: 10.1094/PHP-2006-1214-01-BR.

Coreopsis leavenworthii Torr. \& Gary, commonly referred to as Leavenworth's tickseed, is a native wildflower species distributed throughout Florida. The plant is grown commercially primarily for seed. In May 2005, powdery mildew was observed on greenhouse-grown C. leavenworthii. Abundant conidiophores with conidial chains covered leaves and stems giving the white powdery appearance typical for powdery mildew (Fig. 1). Infection was severe and resulted in the death of some plants. Conidia were hyaline, primarily ellipsoid-ovoid, averaged 33 by $18 \mu \mathrm{m}$, and lacked fibrosin bodies (Fig. 2). Appressoria were nipple-shaped. No ascomata were observed. Based on morphological characteristics, the pathogen was identified as Golovinomyces sp. (1). In order to determine the species of the pathogen, the ribosomal internal transcribed spacers 1 and 2, and the 5.8s rRNA gene were sequenced from two isolates obtained from different greenhouses and compared to sequences in the National Center for Biotechnology Information (NCBI) database. The sequences obtained from the two isolates were identical to each other (Accession No. DQ871605) and to six sequences from G. cichoracearum from various hosts in the Asteraceae. G. cichoracearum has been reported to infect several Coreopsis spp. in the USA, Canada, Europe, J apan, and New Zealand $(2,3,4)$, but this is the first report of $\mathrm{G}$. cichoracearum infecting $\mathrm{C}$. leavenworthii and the first report of it infecting any Coreopsis spp. in Florida.

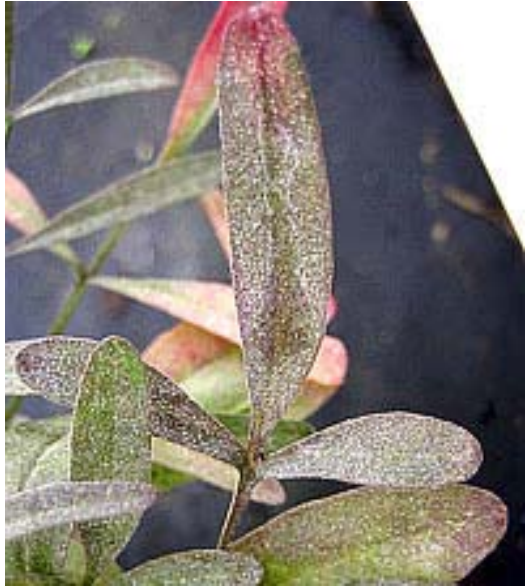

Fig. 1. Powdery mildew symptoms on leaves of Coreopsis leavenworthii.

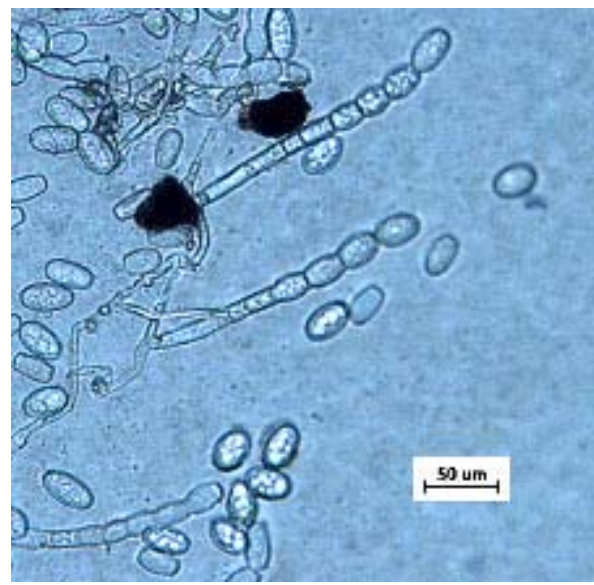

Fig. 2. Conidia and conidiophores of Golovinomyces cichoracearum. 
Nine populations (21 to 28 individuals per population) of C. leavenworthii, five naturally-occurring (two north Florida, two central Florida, and one south Florida) and four commercial populations, grown in the same greenhouse in west-central Florida appeared to display different levels of susceptibility to powdery mildew. Disease incidence and severity ( symptom-free, light $=<10 \%$ of the foliage and stem tissue symptomatic; moderate $=10$ to $60 \%$; and severe $=>60 \%$ ) were recorded on $9 \mathrm{~J}$ une 2005 and again on 15 J une 2005 for all nine naturally infected populations. Data were similar for the two dates and were therefore averaged. Six of the populations (one south Florida, two central Florida, and three commercial) were resistant to G. cichoracearum. More than $90 \%$ of the plants in these populations were symptom-free and the remaining plants were only lightly infected. The two north-Florida populations were moderately susceptable with 50 to $84 \%$ of plants symptom-free, 11 to $40 \%$ lightly infected, and 5 to $11 \%$ moderately infected. The fourth commercial population appeared highly susceptible with only $14 \%$ of the plants symptomfree, $6 \%$ lightly infected, 36\% moderately infected, and 36\% severely infected.

Powdery mildew, caused by G. cichoracearum, on Coreopsis is a significant problem under greenhouse conditions in Florida, sometimes resulting in plant mortality if the disease is not controlled with frequent fungicide applications. Populations and individuals of $\mathrm{C}$. leavenworthii vary in susceptibility to powdery mildew. One of four commercial populations observed was highly susceptible to G. cichoracearum. While commercial production of Coreopsis seed and potted plants predominately occurs outdoors, where symptoms appear to be less severe, the use of resistant populations would likely increase seed production and improve the quality of potted plants.

\section{Literature Cited}

1. Braun, U., Cook, R. T. A., Inman, A. J ., and Shin, H.- D. 2002. The taxonomy of the powdery mildew fungi. Pages 13-55 in: The Powdery Mildews: A Comprehensive Treatise. American Phytopathological Society, St. Paul, MN.

2. Farr, D. F., Rossman, A. Y., Palm, M. E., and McCray, E. B. 2006. Online. Fungal Databases, Systematic Botany \& Mycology Laboratory, ARS, USDA.

3. Glawe, D. A., Grove, G. G., and Nelson, M. 2006. First report of Powdery Mildew of Coreopsis species caused by Golovinomyces cichoracearum in the Pacific Northwest. Online. Plant Health Progress doi:10.1094/ PHP-2006-0405-01-BR. 4. Matsuda, S., and Takamatsu, S. 2003. Evolution of Host-parasite relationships of Golovinomyces (Ascomycete: Erysiphaceae) inferred from nuclear rDNA sequences. Mol. Phylogenet. Evol. 27:314-327. 